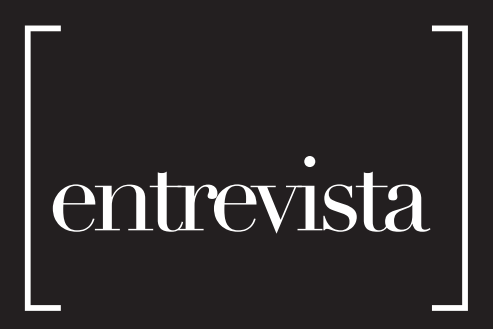

[ ELENI KRONKA ]

Jornalista graduada pela Cásper Libero e mestre em Jornalismo pela ECA-USP com a dissertação A cobertura de moda no jornal diário: do comentário ameno ao status de notícia. É repórter especial do jornal World Fashion, docente da Universidade Anhembi Morumbi e presidente do Conselho Diretivo da Artemoda - Sociedade de Estilo e Cultura. E-mail: ekronka@ig.com.br

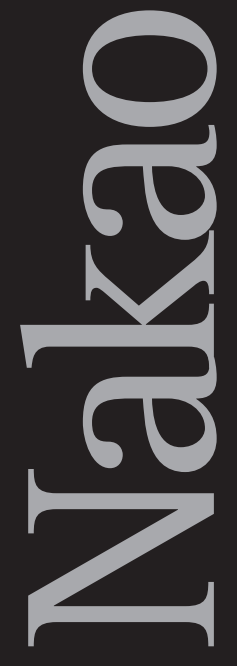

\title{
Um designer de percepções humanas
}

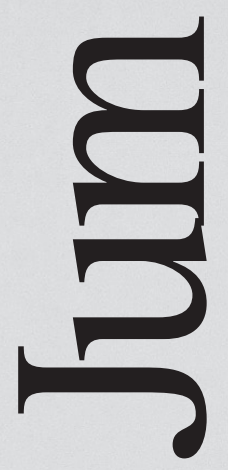

Quando vidas se tornam forma:

diálogo com o futuro - Brasil-Japão

Foto: Luigi Stavale 
0 jovem criador Jum Nakao atingiu a maturidade. E não foi agora. Ela vem justamente do momento em que ele decide lançar o seu olhar de criador sobre o próprio sistema da moda, do qual é legítimo representante. Com as técnicas que domina e a curiosidade de descobridor que the é peculiar, subverte o processo de criação e faz de um desfile seu uma metáfora poética, e ao mesmo tempo crítica, transformando uma sublime coleção de vestidos de papel e um espaço cênico em reflexão epistemológica sobre um dos mais visados fenômenos culturais e sociais contemporâneos.

Assim, Jum analisa a moda pelo avesso e descobre muitos "pontos sem nó" - seja a forma superficial com que a moda ainda é vista, seja pela fragilidade da indústria que a comporta ou mesmo a falha que esvazia o "pensar moda" no momento de sua criação. Mas depara-se também com infinitas possibilidades que podem vir a ser trabalhadas, quer sob o ângulo antropológico, quer sob os aspectos éticos.

A costura do invisível, conceito de moda materializado em coleção e desfile-manifesto, fez o nome de Jum percorrer a mídia e os espaços culturais, como museus daqui e de lá de fora. Mas tudo o que ele quer é continuar a refletir, fazendo com que outros encarem com ele a questão, para que pessoa e moda, isto é, inteligência e cultura, interajam na construção de uma identidade contemporânea.

Em A costura do invisível, trabalho pelo qual é sempre lembrado, você tece uma crítica à moda, transformando o desfile em metáfora. Quais os caminhos de reflexão que o levaram até esse resultado em cena e como se deu a construção do conceito dessa proposta?

Jum Nakao - Para mim, extrapolou tudo o que eu imaginava, não esperava que fosse reconhecido como "o desfile da década" pelo SPFW. Nem imaginei que seria visto como "um dos maiores desfiles do século" pelo Museu de Moda de Paris. Este trabalho já percorreu museus, como o The New Dowse, na Nova Zelândia; o Museu de Arte Contemporânea do Japão; foi exposto na Forteza del Basso, em Florença; no MoMu, da Bélgica; no Atopos, da Grécia; e foi citado em dezenas de livros sobre arte, moda e design. 0 desfile aconteceu numa época em que eu questionava - e ainda questiono muito - as referências, o conteúdo da produção "cultural" e os fenômenos em nosso entorno. Somos expostos a um volume de informação tão grande que as pessoas não digerem mais, não decodificam mais, apenas engolem. Era importante eu realizar um trabalho questionando o conteúdo, o conceito que há por trás da forma. Era preciso materializar um trabalho que, mesmo destruído, mesmo rasgado, permanecesse vivo na memória das pessoas. Era um questionamento sobre a materialidade e sobre o real valor. Quis fazer um trabalho que permitisse vislumbrar que mais importante do que tendências e desenhos vazios de significados é o diálogo estabelecido pela obra com quem a contempla. Quis mostrar que até o efêmero pode ser permeado de permanência, vigorando entre caminhos, valores e ética existentes em qualquer outra área.

\section{Naquele momento, Jum Nakao fazia moda?}

JN - Não era um desfile sobre moda. 0 objetivo era apresentar um vazio repleto de possibilidades e, assim, transformar o nada em algo visível, daí o nome $A$ costura do invisível. A leitura do livro A costura do invisível oferece aos que se interessarem por esse trabalho mais detalhes sobre todo o processo.

Qual a percepção que tiveram a mídia, os críticos e os observadores em geral em relação à sua proposta de criação?

JN - As exposições foram muito bem recebidas pela imprensa e pelo público. Muitos se surpreendem com o fato de a obra ser proveniente do Brasil. A boa recepção por parte dos curadores e instituições desdobrou-se em muitos outros convites e novas exposições. 
Se considerarmos o seu primeiro desfile, no Phytoervas Fashion, até $A$ costura do invisível, no SPFW, como você descreve esses dois momentos do criador e designer Jum Nakao?

JN - Mais do que "derrubar" algo criado anteriormente, prefiro sobrepor, sedimentar, criar base para uma nova perspectiva. Cada camada que criamos, complementa a anterior. Assim é a natureza da evolução.

Você é jovem e, ao mesmo tempo, maduro como designer. É também um criador de vanguarda e uma pessoa que tem presentes em seu trabalho as raízes orientais. Como se dá a sinergia ou fusão desses atributos em seu processo de criação?

JN - Trabalho incorporando o acaso, integrando diversas linguagens, aberto aos riscos, e tudo isso com muito prazer. 0 processo que possibilita produzir as ideias mais criativas é o de experimentar, tendo a chance de errar. Viver o risco do novo, fazer para ver até onde se pode chegar é o que move a criação. Acredito que não se possa conceituar cultura como algo estático e definitivo, mas como algo que se modela com o tempo. Nesse sentido, a influência do meu trabalho não está restrita à cultura japonesa, mas à cultura num sentido amplo e universal.

\section{Como é a sua relação com quem contempla a sua criação?}

JN - Posso dizer que não me atenho ao suporte - roupa ou mobiliário, instalação ou performance. 0 que importa é o observador e as suas possiveis relações e percepções através desses meios propostos. Considero que vestir uma casa é algo muito próximo ao ato de vestir alguém, pois o que se veste, na realidade, é a concretização de uma relação do usuário com o seu entorno. Roupas e casas tornam-se uma extensão de quem as veste ou habita. Há uma relação direta entre o lugar em que se habita e os hábitos, modos e a moda que uma pessoa adota. É bom lembrar que hábito também significa roupa. Moda permeia lugares frequentados, livros lidos, bandas de música, a forma de se expressar e de se receber as pessoas. Permeia também a gastronomia, a cultura que se tem ao redor e, por fim, a roupa. A roupa seria, então, a conexão final entre o habitat interior e os hábitos próprios.

\section{Como você elege os materiais com que trabalha?}

JN - Moda e design podem e devem ser pensados além do produto. Meu foco não está no tipo de matéria, mas naquilo para que ela serve, pois o que modelamos e esculpimos não é o papel ou o tecido, e sim a percepção humana.

Como designer experiente, qual a avaliação que você faz dos diferentes momentos por que o cenário da moda brasileira passou desde o início dos anos 1990, com o surgimento dos primeiros desfiles - Phytoervas Fashion, Morumbi Fashion/SPFW, Semana de Moda-Casa de Criadores?

JN - 0 mercado e o consumidor brasileiro seguem tendências pasteurizadas. Crescemos importando valores. As vitrinas das lojas de roupa nos shoppings são todas idênticas, poderia até ser uma coisa só, sem fachada da marca. 0 povão conhece a Gisele Bündchen e sabe o que é Dior, Gucci, Louis Vuitton. Mas tente perguntar para esse povão quem é algum estilista brasileiro... Não vai saber. A maioria da população talvez até conheça um ou outro, mas não possui poder aquisitivo para adquirir as criações. Pelo menos teriam uma referência de moda brasileira e aspirações, para sonhar em adquiri-la. Infelizmente as coisas pouco mudaram nesses anos. Demos alguns passos, ainda falta muito para dizer que construímos um caminho próprio. É importante continuar caminhando.

Quais foram as dificuldades que você enfrentou ao longo de sua carreira?

JN - Acredito que as principais tenham sido as de qualquer empresário - dificuldades estruturais e conjunturais de um país como o nosso - e as mesmas dos empreendedores da área cultural: a falta de educação e incentivo à boa formação do nosso povo.

Você é um criador "solitário" ou conta com equipe para desenvolver seu trabalho?

JN - Trabalho sempre com a mesma equipe de direção e contratamos novos colaboradores de acordo com a necessidade de cada trabalho. 
como indivíduo. São universos que se tangenciam, que se alimentam de suas vivências. Mas são mundos à parte. Quando se tem uma marca própria, esses contêineres se aproximam numa fusão nuclear complicada. Aprendi muito e, em 2004, decidi romper, rasgar. A costura do invisivel é um rasgar do formato, não da moda. Após esse desfile, abdiquei de minha marca própria, pelo menos por um tempo, para me dedicar à formação de uma consciência sobre a moda e suas possibilidades. Estou no meio do processo, as coisas ainda não mudaram.

0 que você tem em mente, no presente, como continuidade do seu trabalho, em termos de pesquisa de criação?

JN - Acredito ser mais importante fomentar mudanças do que continuar fazendo o mesmo, dia após dia. 0 mundo não precisa de mais roupas. 0 mundo precisa de pessoas melhores. Mas como transformar as pessoas? Acredito que o caminho seja o da educação e da cultura. Em moda, somos todos muito iletrados, alfabetizados apenas como consumidores, porém totalmente sem capacidade de leitura e interpretação. Existe uma grande diferença entre alfabetizar e educar. Tenho me dedicado à educação, pois de que adianta poesia se a escrita não é compreendida? Continuo participando ativamente da moda, como professor, palestrante, realizando workshops e prestando consultoria.

Arte e moda parecem estar cada vez mais próximas em suas criações, o que transparece nas exposições que você tem realizado, como Revolver e Quando vidas se tornam formas. Como isso se dá?

JN - A aproximação entre as áreas de moda e design, tecnologia e arte é necessária. Como escreveu Edgar Morin, a segmentação e compartimentação dos saberes demonstraram-se obsoletas e sem capacidade de respostas para a complexidade que a vivência humana e a sobrevivência do planeta necessitam. Definir, rotular, estabelecer limites são coisas que me soam generalistas demais. Acredito que experiência artística é a relação que transcende obra e observador, é o rompimento de barreiras e de pressupostos, em que se joga um jogo sem regras, limites, convenções e, assim, a transformação acontece. A obra em si é a materialização de conceitos, interface entre o inefável e o real. Ela é palpável e contém um sentido. Mais do que palavras soltas, frases sem sentido, é necessário soprar um pensamento. A integração entre o espectador e a obra é fundamental. Sem essa integração, a obra não existe. Por isso faço "uso preciso do vago" como já dizia Ítalo Calvino, no qual a individualidade encontra seu espaço. Prefiro essa relação com o objeto inacabado, com o saber. Em Revolver, exposição realizada em 2007, em Curitiba, o rato é uma metáfora. Sua imagem está ligada à peste, que se propaga de forma viral, sem controle. É dessa forma que queremos contaminar as pessoas com nossos questionamentos e inquietações. Instigá-las, fazê-las pensar. Expor contradições, destruir convicções.

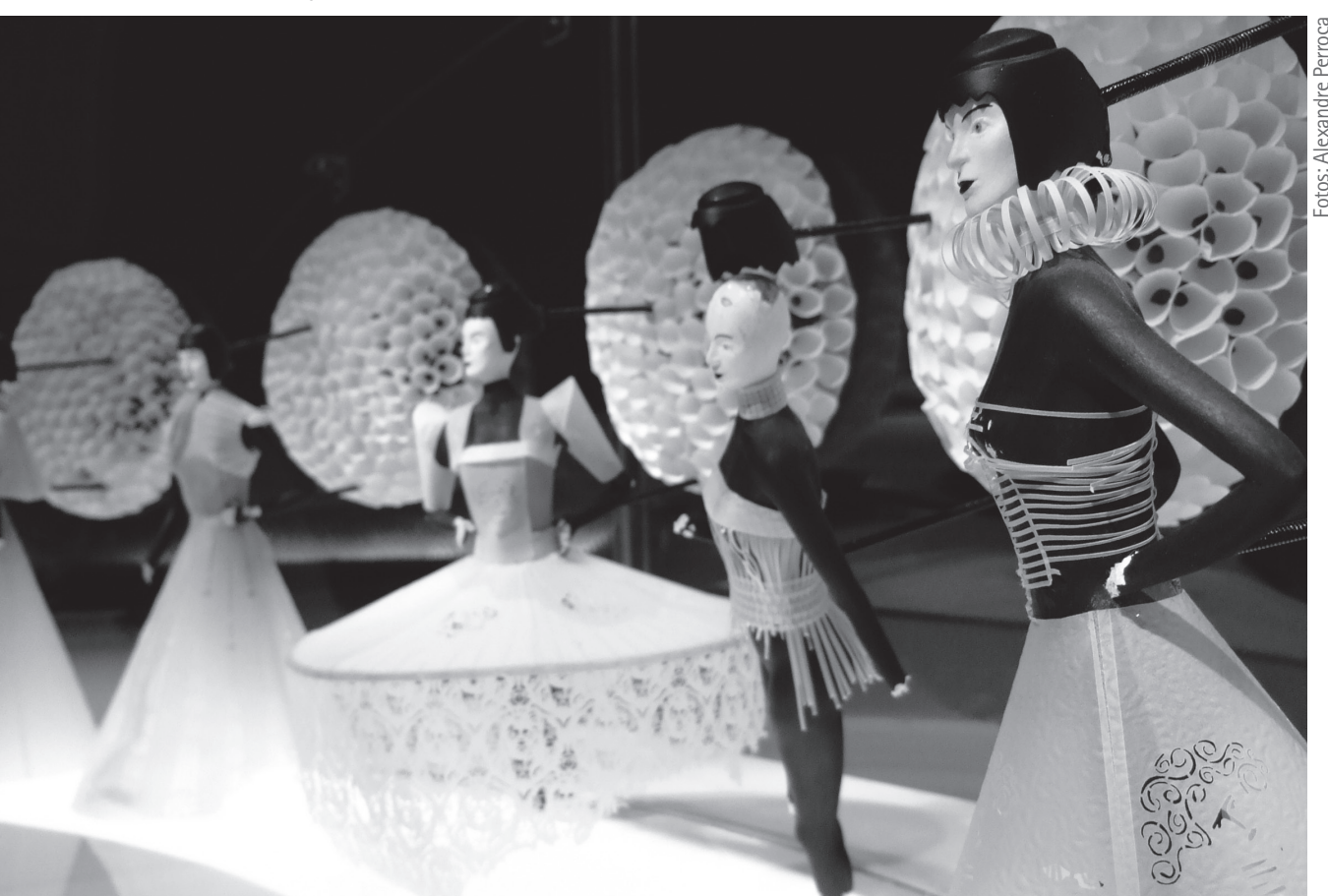


